\title{
Power Relation and White-Collar Crime: Case Study of Coastal Reclamation in Indonesia
}

\author{
Dedy Anung Kurniawan*, Mohammad Kemal Dermawan and \\ Arthur Josias Simon Runtrambi
}

\begin{abstract}
Doctorate Program in Criminology, Universitas Indonesia, Depok, West Java, Indonesia
Abstract: This research aims to understand the power relation and white-collar crime on managing the coastal reclamation and its implication in Indonesia that is very significant at the ontological and sociological level. The problem is very interesting to be analyzed by conducting a qualitative research method based on power theory and crime theory. Data were collected through in-depth interviews, observation, and documentation related to coastal reclamation and its implication in Indonesia. Data were analyzed by using interactive models are data reduction, data display, data verification, and supported by triangulation. The results were based on ontological and sociological levels using criminology perspective for understanding the coastal reclamation and its implication in Indonesia that are needed for providing information to stakeholders related to the regulations and sanctions. This result provides inputs for making better regulation on coastal reclamation policy in Indonesia for state agencies as public officials and practitioners.
\end{abstract}

Keywords: Criminology, Power Theory, Crime Theory, Coastal Reclamation.

\section{INTRODUCTION}

\subsection{Research Background}

Coastal reclamation can be studied from a criminological point of view. Starting from the crimes that occurred in the reclamation process, the power relations between the parties, to the reactions to every crime that occurred. There is a lot of potential for crime from coastal reclamation activities. Environmental crimes that occur in the coastal reclamation process can also be studied using Green Criminology. Nigel South states that an environment is a place or space for a crime to occur such as environmental or ecosystem damage. Green Criminology has to do with measures to prevent crimes such as the crime of environmental damage itself.

Coastal reclamation causes changes in ecosystems and communities, as well as social, economic, and cultural aspects. This needs to be considered by the Government and Developers if you want beach reclamation to run smoothly. Coastal reclamation hurts the community in the form of ecosystem, economic, social, and cultural degradation. Coastal reclamation is not only government plans in development, not only implementation by developers, and not only the community who are affected, but also relationships between parties. There is a reaction from every action taken by each actor, there is even an element of the

${ }^{*}$ Address correspondence to this author at the Doctorate Program in Criminology, Universitas Indonesia, Depok, West Java, Indonesia;

E-mail: dedyanungkurniawan@gmail.com crime that may not be visible from the surface. The relationship between the government, developers, and the community is unequal.

Reclamation is defined as an attempt to repair the damage. Reclamation is defined as an effort to make dry land from the coast. Reclamation is also interpreted as a human effort by using existing technology and resources to change the natural environment around the coast into an environmental landscape. The changes made are by making changes to the shape of the existing landscape and carried out together with all kinds of consequences (Pawitro, 2015).

Law No. 27 of 2007 concerning the Management of Coastal Areas and Small Islands describes reclamation as an effort made by people to increase the benefits of land resources from an environmental and socioeconomic point of view by filling and draining land or drainage. The main values of reclamation include clear and measurable and comprehensive planning on material sources, extraction techniques, and stockpiling techniques by preserving the lives and livelihoods of the people around the reclamation location to preserve the environment. Presidential Regulation of the Republic of Indonesia Number 122 of 2012 explains that reclamation is an activity carried out by people to increase the benefits of land resources from an environmental and socio-economic point of view by way of backfilling, drying of land, or drainage. The United Nations Convention on the Law of the Sea (UNCLOS) does not provide a complete prohibition or definition of reclamation. So until now, there is no 
international convention that agrees on the definition of reclamation

The definition of reclamation mentioned above focuses more on economic aspects than environmental aspects. No agreement can be used as a reference regarding coastal reclamation so that the issue of coastal reclamation becomes subjective and is returned to each country. A more in-depth study is needed on the degradation of ecosystems, social, economic, and coastal culture in the implementation of coastal reclamation which can lead to the emergence of white-collar crime in the power relations of coastal reclamation in Indonesia.

The negative impacts of coastal reclamation include the increased risk of flooding in coastal areas and potential disruption of shipping lanes; Potential damage to coastal ecosystems; Potential damage to seawater quality; Potential damage to the ecosystem at the source location; Potential damage to shore and underwater installations (cables, pipes, gas, etc.); Potential spread of invasive species; Social conflicts due to displacement of people, land acquisition, and disruption of livelihoods.

Coastal reclamation is a project that requires large resources. The two main actors in the reclamation process are the government as the party that gives the permit and the developer as the technical implementer of coastal reclamation. The occurrence of relations between the Government and Developers can trigger White Collar Crime. Based on the description above, there are complex problems in the implementation of coastal reclamation in Indonesia, especially the case of beach reclamation in Benoa Bay, Bali, and Jakarta Bay.

The questions in this study are: (1) How is the environmental, social, economic, and cultural degradation in the case of coastal reclamation? (2) What is the power relation in the coastal reclamation case? And (3) How is the crime that occurred in the case of beach reclamation? The objectives of this study are (1) to understand environmental, social, economic, and cultural degradation in the case of coastal reclamation; (2) to understand the power relation in the coastal reclamation case; and (3) understand the crimes that occurred in the coastal reclamation case.

\subsection{Research Originality}

There is exploratory qualitative research on the impact of reclamation activities on the environment which focuses on environmental and socio-economic changes of fishermen in Batam Bali dan Jakarta, Indonesia. In-depth interviews were conducted with several stakeholders, such as the Implementing Organization of the Batam Bali and Jakarta Fisherman Community Association, and the Batam Bali and Jakarta City Government. The findings of this study indicate that reclamation activities have changed the environment and the cutting of hills and felling of trees in the vicinity for reclamation projects cause flooding and reduce seawater quality. This directly reduces the income of the fishermen and forces them to switch to other professions such as being traders, laborers, and farmers (Priyandes \& Majid, 2009).

Reclamation can be defined as an activity carried out by everyone to intensify the use of land resources from an environmental and socio-economic perspective using landfills and land drainage. From an academic point of view, reclamation means the work of utilizing unproductive areas to become productive and beneficial for the surrounding community. Reclamation can be used to accommodate the needs of settlements, tourism sites, power plants, and conservation of natural resources. But this Reclamation shows a clear negative impact on the physical-chemical environment, biological environment, and social aspects of the area. There are four elements or principles that must be included in the implementation of sustainable development. (1) conservation of natural resources for the benefit of future generations; (2) exploitation of natural resources in a wise manner; (3) fair use of natural resources; and (4) integration of environmental considerations into economic and other development plans, programs and projects. In the Indonesian legal system, there are at least 4 (four) permits that a company must have to be allowed to carry out reclamation; environmental license, environmental protection, management license, site license, and reclamation license. The legal basis for the license is regulated in Law No. 1 of 2014, Government Regulation No. 27/2014, and Presidential Regulation No. 122 of 2012. Laws and regulations on reclamation about the protection of the marine environment, coastal areas, and small islands have accommodated provisions that create sustainable reclamation. Environmental protection provided for in existing laws emphasizes careful planning and environmental impact and risk assessment. Existing laws and regulations can be put to good use for government and private sector leaders to carry out sustainable reclamation (Husin, 2016). 
The cultural anatomy of abuse of power in Indonesia from the perspective of criminology and law impacts deviant actions not only in the depressions of power and moral behavior of public officials. In fact, significant public officials abuse of power is performed by being corrupt or punished, even by severe law, even the perpetrators of power abuses continue corruption or it can be seen that there are no clear effects for corruptors. However, it is a wrong system in the life of nation and state, when public officials who depart from the people do not have a view of life as a nation and state as they should (Riyadi, 2020b).

Culture of abuse of power due to conflicts of interest so that corruption takes too long to in Indonesia. According to Article 33 of the 1945 Constitution, the resources should be controlled by the state for the greatest prosperity of the people. The Indonesian people are not prosperous despite the abundance of resources. The results of the research have occurred abuse of power due to conflicts of interest to maintain power in the management of resources with corruption impacting state losses. This happens change component, caused by global changes and the modernization of the tendency of society to comply with materialism and consumerism while ignoring the cultural values of shame in the life of the nation and state (Riyadi, 2020a).

Corruption behavior of politicians in the parliament and bureaucracy in the reform era is still ongoing. This crime could even be called state-organized crime in a corrupt government. This crime is based on the achievement of individual interests, groups, or political parties and retains the power. The lack of success of the Indonesian government in resolving the case of state officials or politicians involved in corruption, collusion, and nepotism rapidly lightly court decisions, many cases delayed in its prosecution process, even termination of the case of important officials state to be an indication the weakness of law enforcement against white-collar criminals in Indonesia (Riyadi, Wibowo, \& Susanti, 2020).

Agrarian Legal Law is different in every region and State. Agrarian Law describes the land rights, both rights of communal property, rights of individual property, or even King's property or property of the state. Indonesia has adopted individual and communal rights as well as self-government property rights. Land disputes are analyzed through conflict theory; and since related public policy and ownership, then another approach is through the public policy and ownership theory (Riyadi, 2017).
There has been an abuse of power against the power and authority of the state institution of the Indonesian. The researchers suggested that it is better if the legislators of the laws and regulations of the Police of the Republic of Indonesia think about it whether operational accountability. Therefore, there is a check and balance of law enforcement behavior carried out by the police (Riyadi, Hermanto, Harlina, \& Purnomo, 2020).

Until now, environmental crimes still occur. Consequently, there are countless disasters that are happening in a day. However, where is the social control of bureaucrats of the State Ministry for the Environment. The research results showed that the perpetrators of environmental damage were not aware that the impact of environmental damage was more violent than other crimes. It was because this type of crime sometimes had unexpected impacts related to the intensity, duration, and extent of the area affected. Therefore, the efforts to prevent environmental crimes should cover various aspects. These include very strict supervision in terms of check and balance of the independent state institutions as well as the discretion given to the authorities in the disposal of hazardous and toxic waste (Riyadi, Alhamda, et al., 2020).

There has been a conspiracy of abuse of power between investigators and prosecutors, which reflects injustice in the criminal procedure law. This research clarifies a case study of the disparity of prosecution through mutually acknowledged norms and values. Case studies also enable the researchers to study the real thing and gain a better understanding of disparities in criminal prosecution. The result of the research showed that it was suspected that there had been a conspiracy of abuse of power between the investigator and the prosecutor so that there was no justice for the victim (Riyadi, Usman, \& Sudarti, 2020).

Abuse of power in North Sumatra with public officials in the case of the bureaucrats in the Ministry of Environment, so that it occurs environmental damage. Environmental regulation analysis techniques, with analysis using the theory of abuse of power so that researchers draw conclusions deductively and provide recommendations or suggestions according to research objectives. The results found that the actors of the management were not following environmental regulations (Alhamda et al., 2020).

The results of the study show that it has been proven that the state, in this case, the Ministry of 
Research, Technology and Higher Education of the Republic of Indonesia, makes and issues regulations that are very detrimental to the management of private higher education which is minimal in resources. The suggestion from this research shows that the government, by the constitution of the Republic of Indonesia, must be able to provide resource assistance efforts for private universities that are deficient (Rozikin, Sofyan, Riyadi, \& Supriyono, 2021).

Indonesia is a rule of law, which means that there is a guarantee for the functioning of an independent prosecutor in carrying out the judiciary and other tasks and for upholding law and justice based on the state constitution and the prevailing laws and regulations. The Attorney General's Office is a state institution that can carry out or have authority on behalf of the state in prosecution and also has other powers based on applicable provisions. The discretion that is too free for prosecutors tends to abuse power to carry out a culture of corruption in the Prosecutor's Office. Researchers suggest that discretionary power in state institutions is limited and supervised by external agencies on the performance of prosecutors so that checks and balances occur in state prosecutors' institutions (Hermanto \& Riyadi, 2020)

The underground space becomes the solution to the limitations of surface soil. In line with the benefits derived from its use, there is much legal uncertainty about the underground space. This is because there is no law or special regulations that discuss it. One of the fundamental problems in land use is the absence of the law that has made obscurity in the underground space right, whereas the construction of any building or facility above or below the ground must have its legal basis. The most powerful title to the land is an individual property right. This paper seeks to provide input on the issues surrounding the concept of underground space property rights, including 1) the owners of the underground space; 2) the scope of the property rights of the underground space; 3 ) legal acts which may be exercised over the underground space property; 4) obstacles to the implementation of legal action on the underground space property; and 5) justification of property right relationship between underground spaces and land (Riyadi, Atmoredjo, \& Sukisno, 2020).

There is a study using geographic information system analysis tools and statistical analysis to measure land value changes and crime incidence from 2002 compared to the same geographic area in 2005 using paired t-test analysis. Land values and crime statistics were analyzed at the micro and macro levels for comparative purposes. The aim was to demonstrate whether the Brownfield site had any measurable differences compared to control sites that did not receive Brownfield reclamation investments. Three different selection processes determine the location of the controls. The land value test has control locations selected based on attributes such as land-use type, percent of the low-income population, school district, and distance from each other. The crime analysis test has control locations selected based on proximity alone. A bivariate correlation analysis was performed to determine whether there was a relationship between dollars spent on cleanup and the impact on total crime, property crime, and violent crime in 2005 . PostBrownfield reclamation shows that two of the three Brownfield parcel clusters near Brownfield fields increase land values at the level of the same as the comparable control sites. Analysis revealed the value of plots of land within the $1500 \mathrm{ft}$ Brownfield site indicating a statistically significant reduction in land value. However, after the reclamation of Brownfield, the Central Minneapolis control area showed a significant increase in the total value and crime of property, but the neighborhood with the reclamation of Brownfield did not occur (Watkins, 2010)

\subsection{Significance of Research}

Research on coastal reclamation using criminological studies is still little done by researchers. The novelty in this research is the construction of the episteme of coastal ecosystem, social, economic, and cultural degradation as well as the analysis of power relations that occur in the case of coastal reclamation, causing crime in the power relations of coastal reclamation in Indonesia. Research on coastal reclamation from a criminological point of view is useful for the Central Government, Local Government, National Land Agency, Ministry of Environment, Ministry of Marine Affairs, Developers, Fishermen, and the Community as reference material in conducting the reclamation process and further research.

\section{LITERATURE REVIEW}

\subsection{Power Relation Theory}

The theory of power relations was first coined by Michel Foucault, who said, power relations are objective and also widespread, or in other words, power relations are spread in various places and do not stay in a certain place (Foucault \& Kritzman, 2013). 
The theory explains that the power relations created in an area apply to all parties who are objects so that the person or party who is the object must accept the power as a whole. Power relations that occur in one area can involve various parties from various groups so that any party can participate in power relations. According to Foucault, the power problem is regarded as the relations between society, individuals, groups, and institutions in one area.

The theory explains that the parties involved in power relations can come from social groups, individuals, groups, and institutions in an area. These parties come from various layers and groups who are present in social life which of course form different levels of power. The level of power can be seen as the process of power relations goes. The party that initially has great power can immediately lose its power and change its position to low, while the party that initially has little power can immediately enlarge its power and change its position to high. Thus, changes in power can occur in various parties regardless of their position and position in the social environment. Power can arise and develop in various places and is something that can grow and shrink over time, but in this case, it cannot be said that power is weak and indecisive. According to Foucault, power can retreat to reconstitute its strength, invest itself elsewhere, and so on so that the battle continues (Balan, 2010).

The theory explains that the power possessed by a person or party will never disappear from themselves, but their power is at rest and undergoing a process of rearranging its power in the body so that it can fight and dominate the power of another person or party. Recognition and ownership of power must go through a continuous and continuous process, and after the power is recognized and has merged with each of them, the owners of power will make changes to their power, either in a strong or weak condition to remain in power. maintain the existence of power over the opposing party. Thus, the power within a person will continue to experience changes made consciously by the owners of the body. Foucault also adds, Real power is not localized only to the state apparatus and that nothing in society will change if the mechanisms of power that are owned are not changed as well. Thus, the position of the community as a minority group and under the position of the government can have great power if they consciously develop that power, and power cannot change towards being weak or strong without any control from within the individual who has that power (Foucault \& Kritzman, 2013).
Emerson views power as a property of the social relationship, not of the actor. The theory explains that power can only arise when there are social relations between individuals or groups in an area. However, the power does not belong to one of the parties involved, but rather to the relationship formed in it. Therefore, power cannot be created only from one person or party without social relations with other people or parties. After creating social relations, there will be a process of showing the power of each party which later one of these powers will become the power that dominates the power of the other party (Emerson, 1962)

The power that is applied by a person or a party in an area can have a back effect on the power itself. If the power applied is only a prohibition and negative treatment of other powers, then the dominating power will become fragile and vulnerable to setbacks as a result of efforts to release the domination of power by the opposing party. However, on the other hand, if the power gives results in the form of knowledge and positive things for the opposing power, then the dominating power will become strong because it is supported by the power of the dominant party. As a result of this, good relations will be established for all parties to achieve a mutually desired goal. The fate of power relations that occur in an area and involve several parties can be seen from how each party shows its power. If the power shown is only concerned with the interests of one group and at the expense of the interests of other groups, then the power relations that occur will be bad because of the pressure felt by the dominated party. However, if the power is shown is for the common good, then the effect will be good for all parties. The effect of power comes from how it is represented in social life. For example, power can have a negative impact when the head of state regulates the community to comply with the regulations that have been made so that he is recognized as having great power and being able to use the community to fulfill his personal or group interests. On the other hand, power can have a positive effect when the head of state regulates society by creating regulations and policies that are beneficial to all parties and strive to realize common goals. Power relations must have at least two parties involved in them. Because, if it only has one party, it cannot be said to be a power relation. In addition, one party in a power relationship has a certain goal towards the other party, As Emerson said, the dependence of actor A upon actor B is (1) directly proportional to A's motivational investment in goals mediated by $B$, and ( 2 ) inversely proportional to the 
availability of those goals to $A$ outside of the $A B$ relation (Emerson, 1962).

The power that is formed in a power relation can have a certain purpose under the will of the power owner, namely the dominating party. For the dominant party, their power is only a group property that can increase or even disappear at any time. According to Cartwright, (1) power can function as coercion, and (2) power can function as a determination of behavior. The theory explains that the power created in a power relation can be coercion and violence. The dominating party can use their power as a way to fulfill their wishes but at the expense of the interests of the dominant party. On the other hand, power can determine the behavior of the object. The dominated party will follow the rules that are the product of the dominating party's power to achieve the formation of behavior designed by the dominating party. The behavior created as a result of this power can be positive or negative following the values contained in it.

Power relations between the government and society can be categorized as power relations from one group to another. This happens because the number of members of each party is more than two people. The government, led by the head of state, can create negative power relations with the people if they cannot run a government system capable of realizing common interests. Leaders become leaders because there is a need in society for people like those who are elected and because they are the ones who carry out the actualization of needs, are those who will influence and urge people to carry out what they suspect are the wishes of the community. The theory clearly shows that the election of a leader to run the government system is not necessarily following what the people want. Therefore, a negative power relation arises that involves the government and the community. In this case, the power of the government can apply in full to regulate the community, both from public and private matters.

\subsection{Crime Theory}

Edwin Sutherland is a scientist who introduced the term White Collar Crime. Sutherland focused on crimes committed by people in the upper classes of society, in contrast to the general belief that crimes were committed only by people of lower status. Because white-collar crime is tied to the professional class and corporate crime elites are linked to white-collar crime. Corporate crime relates to the company as a distinct entity. This benefits the company as a whole which may include investors and individuals in high positions in the company. White-collar crime and corporate crime are similar in that they are both involved with business. The difference is that white-collar crime benefits individual crimes and corporations benefit corporations (Sutherland, 1972).

Crimes committed by someone who is respectable and has a high social status in society are called whitecollar crimes. The application of the term white-collar crime or white-collar crime refers to business managers and executives. Another statement regarding whitecollar crime is found in the journal entitled 'Assessing the Perceived Seriousness of White-Collar and Street Crimes', that white-collar crime is an unethical illegal act where the act violates responsibilities and trust in the context of its work activities legitimized by people of high social status or respect for personal or organizational interests. White-collar crime is also usually understood as a non-violent crime committed by a prominent person (Benson \& Simpson., 2009).

The perpetrators of white-collar crime are a heterogeneous group that has the characteristics of their background, their involvement in the violations committed, their awareness that they have violated social norms and legal norms. In his understanding, white-collar crime is divided into several typologies based on 3 factors, namely the importance of the social status of the perpetrator, the meaning of his work activities, and the possibility of violating the law. The categories that are divided into white-collar crimes are based on the categories of perpetrators, namely occupational crime and organizational crime. Whitecollar crimes committed in groups or organizations are carried out to benefit the group, while for the perpetrators who commit these crimes individually, this is usually done as a way to take advantage for themselves.

In occupational crime, white-collar crime can be committed by individuals who have expertise in certain fields known as crimes of professional occupation, namely someone who has a professional or professional occupation, such as a doctor, lawyer, teacher, lecturer, or accountant. In this category, the profit sought takes advantage of the profession that is occupied by a person and the profit is aimed at him as well by using illegal means. These illegal methods are carried out in various forms of crime, including fraud, data misappropriation, bribery, malpractice, and other forms of professional misappropriation (Cliff \& Desilets, 2014). 
Professional work or what is commonly referred to as a profession is a job that has a scientific basis where to get the job a special school or education is needed. In this context, someone who already has special knowledge and expertise can take advantage of their profession and professionalism to be able to provide services for the community according to the field they are engaged in because the knowledge they have gained is applied science or advanced science. In addition, people who have certain professions have respectable positions and positions or have high social status (Elliott, 1973).

Having professional status is considered as the highest social prestige. In some cases of white-collar crime, there are policy violations based on the code of ethics of each field that is controlled or made following the profession. Professional work has great opportunities concerning white-collar crime. This can happen because their work as professionals has an impact on increasing their standard of living both economically and socially. This opportunity is often used by professional workers to commit white-collar crimes and gain profits for themselves (Newman, 1958).

Green explained that there are 4 types of occupational crime. Occupational crime is a crime committed based on opportunities and benefits derived from a legal work environment (based on one's job), and the punishment is regulated by the legal system. Based on this definition, occupational crime can be carried out by various legal fields of work, both upper and lower classes, so that occupational crime can be categorized as white-collar crime or not. The four types of occupational crime are organizational, state authority, professional, and individual. First, organizational occupational crime is explained as the equivalent of corporate crime, namely crimes committed by corporations or organizations through corporate structures, corporate policies, corporate goals, and corporate resources. Examples are employment contract fraud, environmental pollution due to production waste. second, state authority occupational crime is explained as a crime committed by abusing power or authority by someone who has a high position or position in an area. An example is a violence by police officers. Third, is a professional occupational crime, which is a crime based on work in special fields that can only be carried out by someone professional. Examples are malpractice by surgeons or sexual harassment by doctors using drugs to make the victim unconscious. and fourth, individual occupational crime, this category is said to be not related to a person's work directly, but related to the income or salary that a person earns through his work, and an example is income tax falsification (Green, 1990).

Organizational occupational crime can be defined as a form of white-collar crime committed by members of a company driven by efforts to increase profits for the company, or company executives, either by involving the company's organizational structure as a whole or only certain people, for example, company leaders. The definition of organizational occupational crime is similar to the notion of corporate crime, but organizational occupational crime is not a crime in the name of a company, but a company that commits a crime, meaning that a crime is a legitimate company action or decision, but can violate legal rules and have a negative impact. for other parties, such as environmental damage, contract fraud, lack of security in the work environment, and so on. Crimes by legal work organizations or Organizational Occupational Crimes can be categorized into 4 namely Organizational Occupational Crimes against workers, against consumers, against the environment, and bribe giving.

Organizational Occupational Crime against workers is a crime committed against workers informal organizations such as forcing a target for the amount of production that must be completed, no guarantee of work safety, and disproportionate wages for workers. Organizational Occupational Crimes against consumers are crimes committed against consumers, such as fraud aimed at consumers to attract consumer buying interest and selling power through various means such as excessive advertising, manipulation of consumer comments on a product, coercion to use company products, and price manipulation. Organizational Occupational Crimes against the environment are actions that damage the environment, for example, the disposal of hazardous waste into a watershed for an area, or forcing drilling on land that can harm the environment and surrounding communities. Organizational Occupational Crime bribe giving is a crime committed by a company to get recognition for its legal organization or for the products it produces, this is done to get a good image of the company, for example bribing research institutions to get good research results, fraud in invoices and returns, conspiracy in the auction.

Corporate crime is corporate behavior or employees acting on behalf of the corporation, which is prohibited 
and punishable by law. The definition of this crime can be categorized into two categories, namely: firstly the employee or company did something wrong, and secondly, the company faced wrong against itself. Both of these categories lead to corporate crime. In many cases, the criminals are separated from the company but over the last few decades, it is seen that the company has hidden some faces behind it and saved them from punishment. Company behavior has been regulated by company law for a long time. It's time for corporate responsibility for criminal wrongdoing to be addressed. makes the company responsible for the actions of its agents when employees act within their scope of work and create profits for the company by those actions (Braithwaite, 2010).

In corporate crime, both organizations and individuals can be illegal offenders and can be held accountable for their crimes. Work crimes can be labeled as crimes against the organization. Because such companies become victims of crime when they suffer losses as a result of violations committed by anyone including employees and managers. Individuals or groups commit crimes at work. Examples are embezzlement, theft, tax evasion, sales manipulation, fraud, etc. Corporate crimes are committed collectively or individually on behalf of the company. Because these individuals or groups carry out criminal work for their purposes, and not for the enrichment of the organization as a whole. Most corporate crimes are committed at higher corporate levels, for example at the level of management or manager positions, and involve employees at all levels (Dugan, L., \& Gibbs, 2009).

State corporate crime is a concept that refers to crimes committed in connection with State policies and commercial corporate policies and practices. State corporate crime is distinguished from corporate crime which refers to irregularities in the context of corporations and by corporations. This is also different from political crimes directed against the State. Nor are these 'State Organized Crimes' which are crimes committed by Government Organizations (Michalowski \& Kramer, 2007).

\section{RESEARCH METHODS}

A qualitative approach is used in this study to understand the power relations that occur between 3 parties, namely between the government and the developer, the government and the community, and the developer and the community. Qualitative research was conducted to describe the power relations that occur between the parties who have direct and indirect interests (Creswell, 2009). This research was conducted to identify ecosystem degradation, power relations, and white-collar crime that occurred in coastal reclamation cases in Benoa Bay, Bali, and Jakarta Bay. The first step is to collect information from various mass media. The second step is to collect information from Government Officials, namely the central government and local governments. The third step is to collect information from the Developers. The fourth step is to collect information from the public and academia.

Data Collection was obtained from parties related to coastal reclamation issues. For primary data, researchers took primary data for reclamation on the North Coast of Jakarta and Benoa Bay, Bali. The two places were chosen because they are quite representative of commercial beach reclamation in Indonesia. In addition, the reclamation of the North Coast of Jakarta and Bali's Benoa Bay has also become a national concern to this day. The reclamation of the North Coast of Jakarta is full of pollution and socio-economic problems, the Reclamation of the Bay of Benoa Beach of Bali is full of socio-cultural problems. Primary data collection was carried out by indepth interviews with informants who were directly related to this problem. (1) Government; (2) Coastal Reclamation Developers; (3) Community, Fishermen, and Non-Governmental Organizations. Secondary data collection is done by collecting data on coastal reclamation in Indonesia from scientific works published in national and international journals. In addition, researchers also collect regulations regarding the terms and conditions for implementing coastal reclamation for commercial purposes.

Data analysis was carried out by following the steps described by Miles and Huberman. Interview data analysis includes data reduction, data display, and data verification. Data reduction was carried out on the interview transcripts by taking some of the most important relevant words and giving the necessary markings. Data display is done by providing relevant coding to provide categorization to find sub-themes. Data verification is carried out to obtain conclusions and general themes of the findings (Miles \& Huberman, 1994). Case analysis was carried out using case descriptions and cross-cases. After the description of each case, a cross-case analysis was carried out. What is meant by cross-case analysis is to compare the first case with the next case in terms of similarities 
and differences. By applying general analysis, namely treating cases fairly to produce cross-case analysis that supports each other and contradicts each other. After a cross-case analysis has been carried out, interpretation of the research findings can then be carried out (Yin, 2009).

\section{RESULTS ANALYSIS AND DISCUSSION}

\subsection{Case in Benoa Bay Bali}

\subsubsection{Results of Interviews with the Government}

Regarding the beach reclamation in Benoa Bay, forums have been repeatedly held to accommodate suggestions and input from those who agree and those who reject the reclamation. Rules that are the reference in the reclamation of Presidential Regulation Number 51 of 2014 concerning Amendments to Presidential Regulation Number 45 of 2011 concerning Spatial Planning for Denpasar, Badung, Gianyar, and Tabanan urban areas. This was explained by Government sources:

"There is a presidential regulation number 51 , there are changes on the one hand to improve the welfare of the community from the socio-cultural and environmental aspects" (Interview with Government, March 2021).

The Benoa Bay area can be used as an area for economic, socio-cultural, and religious development. The 2014 Presidential Regulation states that the limit for reclamation and revitalization can be done up to a maximum of 700 hectares. The same thing was also obtained from the interview results as follows:

"All from the central government, we are only facilitating the reclamation which is approximately 700 hectares wide, up to 11 islands or 12 islands and their condition is now stagnant' (Interview with Government, March 2021).

Until now, the Benoa Bay reclamation process has stopped, but waves of resistance are still running from elements of the community. The informants of this research stated that:

"...many do not support it, from environmental institutions, civil society organizations working on environmental issues and so on, including indigenous peoples everywhere" (Interview with Government, March 2021).
The refusal made by indigenous peoples and civil society organizations is certainly not something that is done without basis, some things underlie these rejections. There is a rejection from the socio-cultural aspect, related to the sacred place that is believed to be in Benoa Bay:

"The customs are still strong, the problem here is that sir, the customs are still strong, as far as I know, because there is a sacred point in Benoa Bay" (Interview with Government, March 2021).

However, later on, the informants stated that they as implementers and parties that facilitated the reclamation process were also faced with confusion from various rules and directions which then stopped the reclamation process:

"...the presidential regulation has not been revoked, the old one is still there, the governor is asking for direction from the ministry of home affairs, to think about it, now the situation is stagnant, sir" (Interview with Government, March 2021).

The problem of coastal reclamation in Benoa Bay can only be done based on reports, be it the government, developers, and also community and community groups. However, until the decision to cancel the reclamation in Benoa Bay, the Bali Police have not received a report. During the implementation of large-scale demonstrations, the Bali Police only carried out supervision so that the demonstration did not hurt everyone, including the emergence of criminal acts.

\subsubsection{Results of Interviews with the Developer}

The beach reclamation developer for Benoa Bay has not been operating for a long time, so the author was unable to interview representatives from the developer. One of the former Development Staff was not willing to interview so the writer used secondary data. Beach reclamation in Benoa Bay is part of the overall revitalization of Bali. The developer seeks to improve the social, cultural, and environmental lives of the Balinese people. Even environmentally-friendly infrastructure and building educational centers. The Benoa Bay reclamation has been carefully and carefully planned to benefit the Balinese people. Developers will try to comply with applicable regulations so that they will focus on meeting the requirements set by the government. The emergence 
of a movement to reject the reclamation by holding large demonstrations is a natural thing because there will always be pros and cons. The way to overcome problems in Bali through reclamation which is part of the revitalization is that it can still maintain the lives of the people and the environment in Benoa Bay.

\subsubsection{Results of Interviews with the Community}

The Community Informant explained that he was involved in the resistance movement from the start:

"The reclamation has made us miserable, our house has been inundated with water or flooded. Even though it was raining heavily before, our house was never flooded. So we are still traumatized by reclamation" (Interview with Community, March 2021).

According to the community, they become victims if the reclamation is carried out. Community Informants explained that:

"We are traumatized by the reclamation which cost us. Fish catches are reduced and floods often occur. If the reclamation is carried out, how can there be fishermen, from the very beginning we intended to demand that the reclamation be stopped so that when that goal has been achieved, it means that our struggle is over, we have no intention to legally prosecute the people and institutions involved in the implementation of the reclamation in Benoa Bay? (Interview with the Community, March 2021).

The Benoa Bay area has always been a location for cultural activities. Benoa Bay is trusted by the Balinese as a Sacred Area. Benoa Bay and Mengroove Forest play an important role in maintaining the balance of the ecosystem, namely the barrier to tidal water that can cause floods and hurricanes. Benoa Bay provides great benefits for the economy of the surrounding community. By continuing to preserve the Benoa Bay Area, the social life of the surrounding community runs normally. Changes in the ecosystem in the Benoa Bay area have disrupted the cultural, economic, and social life of the community. The reclamation causes the coastal communities of Benoa Bay to be flooded when the tide is high and when it rains heavily. In addition, the economic impact for fishermen is felt because the catch is reduced.
Benoa Bay reclamation has many legal problems. Presidential Decree No. 45 of 2011 concerning the Denpasar, Badung, Gianyar, and Tabanan (Sarbagita) urban areas states that Benoa Bay is a Nature Reserve, Nature Conservation and Cultural Conservation Area, which consists of Ngurah Rai Forest Park, Sangeh Nature Tourism Park and Conservation Area in coastal areas and small islands. The management of the Sarbagita area is no longer the authority of the Bali Provincial Government but is the authority of the Central Government. Sarbagita cannot be used as a reclamation site for any reason. Presidential Regulation of the Republic of Indonesia No. 122 of 2012 states that reclamation is not allowed in conservation areas and sea lanes.

However, the Bali provincial government in 2012 issued a decree granting permission to the developer to carry out reclamation. Violations of the law do not only occur at the provincial level, but also at the national level with the issuance of Presidential Regulation Number 51 of 2014 which removes the articles that state that Benoa Bay is a conservation area, and replaces Benoa Bay as a public use area so that Benoa Bay can be reclaimed. In November 2019, the Minister of Maritime Affairs and Fisheries extended the reclamation location permit through an extension of the previous permit for reclamation for tourism development purposes. So it is clear that the provincial government and the central government accommodate reclamation developers by changing the regulations on reclamation.

The degradation of the environment, economy, society, and culture caused by coastal reclamation creates power relations that occur between the community, businessmen, and the government which then raises new policies from the government which lead to acts of crime and intimidation to the public.

\subsection{Case in Jakarta Bay}

\subsubsection{Results of Interviews with the Government}

According to informants from the Government, the Ministry of Maritime Affairs and Fisheries has the main task of handling reclamation functions. Broadly speaking, reclamation has two main focuses:

"Reclamation in Indonesia is for two purposes, one for the interests of ports which are the domain of the Ministry of Transportation, the provisions of policies, regulations, laws, permits, all of which are 
provisions of the Ministry of Transportation. But other than that, reclamation follows the provisions of the ministry of marine and fisheries. Coastal reclamation in Jakarta is not related to sports, so it generally follows the provisions issued by the ministry of marine and fisheries" (Interview with Government, May 2021).

Reclamation is regulated in Law No. 27 of 2007 which was later strengthened by Presidential Decree No. 112 concerning Reclamation Permits. In its development, Law No. 27 of 2007 was revised to become Law No. 1 of 2014 and then updated in the Omnibus Law which was ratified. According to an informant from the Government that the government agency that oversees the reclamation has played a role following its main duties and responsibilities. What has not been completed is the issue of licensing in other ministries such as the Ministry of Environment and Forestry.

"The Ministry of Maritime Affairs and Fisheries has issued a location permit. The Ministry of Environment and Forestry has not issued an environmental permit, maybe later we can ask why the environmental permit was not issued." (Interview with Government, May 2021).

In this case the researcher found irregularities in the bureaucratic process. The Ministry of Maritime Affairs and Fisheries always gives a location permit for approximately 6 years but the Ministry of Environment and Forestry does not give an environmental permit. If there are things that are incomplete or inappropriate, inter-ministerial ministries should be able to coordinate before issuing permits. However, the Ministry of Maritime Affairs and Fisheries continues to issue permits to smooth the reclamation process even though no environmental permits have been issued yet.

"They applied for a permit in 2014 and we extended it until 2018, we issued a new permit referring to Presidential Regulation 51, then in 2020 they submitted a new application" (Interview with Government, May 2021).

If viewed on a macro scale, of course this can be said as a neglect of the Ministry of Marine Affairs and Fisheries on environmental aspects. Although the
Ministry of Maritime Affairs and Fisheries does not oversee environmental permits, and the Ministry of Environment and Forestry has not issued environmental permits, the Ministry of Maritime Affairs and Fisheries should consider and review them in granting re-permits. Thus, it appears that there is a lack of coordination between institutions so that the granting of the extension permit is a reflection of the Ministry of Maritime Affairs and Fisheries' neglect of environmental aspects.

\subsubsection{Results of Interviews with the Developer}

According to the developer, the coastal reclamation in Jakarta Bay can be carried out because it is a central government program since 1995. Presidential Decree no. 52 of 1995 concerning the Reclamation of the North Coast of Jakarta states that the North Coast of Jakarta is a strategic area for the economy and development of the city so that reclamation is necessary.

"Coast reclamation in Jakarta Bay is legal because it is part of the development of the DKI Jakarta Provincial government. Because the DKI Jakarta Provincial Government does not have the budget to carry out reclamation, it invites the cooperation of the private sector" (interview with Developer, June 2021).

Since 1997, the Developer has had a cooperation agreement with the Provincial Government of DKI Jakarta to carry out reclamation but it has not gone well and can only be implemented in 2012 after all regulatory requirements are met. Developer obligations have been carried out, but the obligations of the DKI Jakarta Provincial Government have not been carried out.

"The problems experienced in carrying out reclamation are the complexity of applicable regulations and bureaucracy. It should be following the cooperation agreement, the government is obliged to assist with the administration of administrative requirements, but we take care of all the requirements without government assistance. The many conflicting rules that we have experienced, as well as the sectoral egos of each institution, are still happening. This makes the administrative requirements to carry out reclamation only completed in 2012. So it takes 15 years to take care of the 
administrative requirements" (interview with Developer, June 2021).

The purpose of carrying out the reclamation, among others, is to implement Presidential Regulation no. 52 and 73 of 1995 . This is also based on the real condition that the North Coast of Jakarta has been polluted and the waters have been damaged by various domestic wastes and are in a worrying category.

"With reclamation, it will bring many benefits including polluted seawater becomes clean, reduces flooding and tidal waves because it has embankments, increases groundwater levels, opens new land for housing and settlements, increases the availability of decent green open spaces, provides public facilities and social justice, increasing social justice, improving the balance of life, as well as developing the economy and the region" (interview with Developer, June 2021).

In the implementation of reclamation until now, the problem faced by the Developer is the long and difficult bureaucratic process.

"We carry out various socialization, education, and religious activities to the community around the location. We routinely provide compensation for grief, compensation for orphans and fire victims. We provide sports assistance and coaching. We also provide fishing gear needed by fishermen. Provide garbage shelters for cleaning, build gates, provide guidance, provide basic needs, assist posyandu activities, provide assistance for teaching and learning needs, and early childhood education. So in general our relationship with the surrounding community is good. Even if there are problems, only a few residents and we always invite people who have problems to have a dialogue. Most of the problems in society arise because of fake news that is easily spread through social media" (Interview with Developer, June 2021).

According to the developer, the ideal reclamation is a reclamation that can accommodate all interests, be in the interests of the government, the community, and developers. Although it may not be one hundred percent ideal, at least it is close to ideal.
"Everyone's idealism is different and everyone wants to benefit. developers want to license to be simplified, legal certainty, and protected, government policies must be consistent, so that investment is not half-assed. The community must be given access, not hindered. The community's economic awakening with the reclamation so that it provides benefits. The government itself with the reclamation will get many benefits. All sectors will be lifted, income taxes will go up, so will the rest of the economy. Environmental problems can be overcome, with the rocks around the reclamation being able to become marine biota, the wastes are covered with sand so they don't become toxic gases. The point is that in the implementation of reclamation the positive value must be greater than the negative value" (interview with Developer, June 2021).

\subsubsection{Results of Interviews with the Community}

Informants from the community explained that one of the bases for reclamation was Presidential Decree No. 52/1995, as a follow-up to Presidential Decree No. $17 / 1994$ on the Five-Year Development Plan. Presidential Decree Number 52 of 1995 is still used as a reference today:

"From the history of the first Presidential Regulation in 1995, which became a reference and it is a continuation of the last Presidential Decree concerning the Five-Year Development Plan. The authority and responsibility for the North Coast Reclamation rest with the Governor of the Special Capital Region of Jakarta" (Interview with the Community, April 2021).

The Presidential Decree became even stronger after the issuance of Regional Regulation Number 8 of 1995 which became the legal basis for the running of the Jakarta reclamation project from the past until now. There is also a Governor's Regulation to support and smoothen the reclamation process, namely Gubernatorial Regulation No. 121 of 2012. Of course, the ratification of the Gubernatorial Regulation is full of political importance considering that it was ratified at the end of the term of office, but then the Governor's 
Regulation continues to run and strengthens the reclamation plan for the north coast of Jakarta.

Regarding this reclamation, it was later transformed into the baton of Jakarta's leadership. In addition, the length of the reclamation relay can be concluded that there is indeed an omission by the Provincial Government of DKI Jakarta and the Central Government. The wave of rejection of reclamation continues from year to year, but the process continues, no matter who takes office. Whereas reclamation itself can be used for various better things, reclamation can be done from an environmental perspective to make improvements/repairs on the environment rather than being used for commercial purposes.

"This reclamation does not fulfill environmental interests at all because it is only an investment interest, so it is not a recovery effort that is being carried out, the reclamation of the creation of a new island is for commercial purposes. from the literal side, this reclamation makes a location returned to be more useful, for example planting mangroves, making forests, and fishing settlements. But the notion of reclamation has shifted to a new land, for commercial purposes" (Interview with Community, April 2021).

The movement against reclamation itself is certainly not without foundation, various bad impacts have been felt by the community. Starting from the damage to marine biota and ecosystems, the influence on the socio-cultural context of the community, even to personal noble values such as customs. Some of the impacts related to the ecosystem are as follows.

"Jakarta Bay is experiencing an ecological
crisis and there are still many thousands
of fishermen who depend on coastal
ecosystems, besides causing pollution.
reclamation changes oceanography"
(Interview with Community, April 2021).

\subsection{Discussion}

\subsubsection{Degradation of Environment, Economic, Social and Cultural in Coastal Reclamation Cases}

In the case of beach reclamation in Benoa Bay Bali, it was found that the community and fishermen around Benoa Bay Bali are still "traumatized" by the reclamation that has been carried out previously. The reclamation has had a negative impact from implementation to completion, namely floods and tidal waves. These things make the Balinese people realize that if they remain silent, the beach reclamation project will continue and the community will feel the negative impact again. Benoa Bay Bali is a sacred area that has existed for hundreds of years. Support from the international community wants Bali to remain "authentic" with a variety of cultural customs that are not found in other areas. The rejection of the Balinese people is increasingly evident with the presence of billboards in various strategic locations in Bali such as Denpasar City. Balinese traditional community leaders also support the rejection of beach reclamation. The dominant narrative is not only the damage to the environment and marine ecosystems but the narrative that Benoa Bay is a sacred area for the Balinese people succeeded in mobilizing the Balinese people to carry out peaceful demonstrations that paralyzed Denpasar City. This moment shows the government and developers, even though the power relations between the fishermen and the coastal communities of Benoa Bay are considered weak, it does not mean they have lost. Because of the peaceful demonstration, the government finally decided that the Beach Reclamation in Benoa Bay Bali was canceled.

In the case of beach reclamation in Jakarta Bay, there are fundamental differences, so that beach reclamation is still being carried out today. This is because the negative narratives of the Jakarta Bay reclamation are not a national issue and are only carried out by a small number of coastal communities affected by the reclamation. Coastal reclamation in Jakarta Bay is an official program of the Government as stated in a Presidential Decree. Developer XYZ was appointed as the executor of the reclamation because the Government did not have the funds to carry out coastal reclamation. The developer carrying out the reclamation has followed the applicable regulations and has carried out socialization and involves the surrounding community. Jakarta as the State Capital with the characteristics of a heterogeneous and modern society makes the reclamation of the North Coast of Jakarta one of the solutions to some of the problems that exist in the community, especially the problem of employment. Coastal reclamation in Jakarta Bay was made and used as a political tool to attract votes during regional head elections. There is an attempt to narrow the narrative as if a reclamation is just a political issue. Starting from the problem of the ecosystem, social, economic, and cultural degradation, 
to economic and livelihood problems, reclamation is an unsolvable thing. The narrowing of the narrative is also unavoidable considering that the relationship between actors who advance themselves in politics is supported by various political parties that are stronger than the community. Political parties can influence policy through their cadres in parliament, while the public does not have the power and authority.

\subsubsection{Power Relations in Coastal Reclamation Cases}

Power relations are latent in social life. In the case of Indonesia, power relations are seen in the relationship between the government and the community. For example, in the case of coastal reclamation, power relations are seen between coastal communities and government actors, such as the Ministry, City Government, Provincial Government, and up to the Central Government. Power relations are formed because of the authority and power possessed by the government. All government actors have stronger power relations than developers and the community. Power relations cause the community to be the aggrieved party because they are powerless in social life. Communities are forced to submit to and follow directions, rules, policies, and various decisions made and regulated by the Government. The government becomes a party that is very influential and has power that is difficult to resist.

The case of beach reclamation in Benoa Bay Bali shows that there is a power relationship between the Government and the Developer with the issuance of a provincial government decree stating that $A B C$ Developer has the right to reclaim Benoa Bay Bali. The decision letter violates the above legal rules that beach reclamation in Benoa Bay Bali is no longer the authority of the Bali Provincial Government but is the authority of the Central Government. Thus, it appears that the power relations of the community are very weak against the Provincial Government and the Central Government.

The case of beach reclamation in Jakarta Bay is not much different from that of Benoa Bay in Bali. The power relationship between the developer and the government is very strong because the DKI Jakarta Provincial Government has a cooperation agreement with the $X Y Z$ Developer. However, it is different from the relationship between the developer and the community which looks better when compared to the one in Benoa Bay, Bali, where there are still several groups of fishermen who reject the reclamation.

\subsubsection{Crime in in Coastal Reclamation Cases}

The White Collar Crime in the coastal reclamation case in Benoa Bay is neglected, there is no transparency, there is no community involvement, and permits are not finalized. This neglect and omission can be seen from the lack of response to the rejection by the community. The rejection movement that has been carried out for years does not get a response, is not heard, and is ignored by the Government. Transparency is also a serious problem that has not been resolved, such as transparency of requirements and completeness of reclamation documents, transparency of processes and budgets, as well as transparency and socialization of the impact of the reclamation process. Likewise, the location permit granted indicates the existence of an organized crime.

The State Authority Occupational Crime in the case of beach reclamation in Benoa Bay Bali is the Provincial Government issued a Decree that permits the Developer to carry out reclamation in Benoa Bay. Although many rejection movements have been carried out and environmental permits have not been granted by the Ministry of Environment and Forestry, the Ministry of Marine Affairs and Fisheries, the Provincial Government of Bali has given a location permit for coastal reclamation. The community is faced with a disadvantaged situation but does not have the power to fight back because, in terms of power relations, they are weak and lose in authority and power. In the case of coastal reclamation in Jakarta Bay carried out by the Developer, any breach of the Cooperation Agreement between the Developer and the Provincial Government of DKI Jakarta is a default in the category of State Authority Occupational Crime. The DKI Jakarta Provincial Government as the ruler has neglected and arbitrarily treated the cooperation partners.

Professional Occupation Crime was found in the Benoa Bay reclamation case carried out by the Bali Provincial Government by issuing a Decree in 2012 . This violates the rules set by the Central Government, that since the beginning of 2012 the problem of Benoa Bay reclamation has become the responsibility of the Central Government and not the Government Bali province. In the case of coastal reclamation in Jakarta Bay, there has been a default by the DKI Jakarta Provincial Government to the Developer which is the responsibility of the DKI Provincial Government.

Organizational Occupational Crime against Consumers, namely crimes committed by organizations 
on their consumers. This happened in the reclamation of the coast in Jakarta Bay by developers who did not keep their promises in providing land and buildings that had been purchased by consumers. Developers should hand over land and buildings in November 2017 because consumers have already completed payments. However, the developer does not provide land and buildings that have been paid for by the consumer. The developers reasoned that they were also victims of the policies of the DKI Jakarta Provincial Government.

Organizational Occupational Crimes against Environment are actions that damage the environment due to exploitation and destruction of the environment. Beach reclamation in Jakarta Bay is needed because there is pollution by hazardous waste so that beach reclamation is a way out so that hazardous waste in Jakarta Bay does not emit toxic gases that will damage the environment and fishermen.

\section{CONCLUSION}

The existence of power relations between regulators who have reclamation authority and communities affected by reclamation is not only in the aspect of power and authority but also planning, organizing, actuating, and controlling in the coastal reclamation process such as the occurrence of neglect of socio-economic cultural aspects perceived by the community. affected by reclamation. The power relation gap opens up opportunities for White Collar Crime to occur. The existence of an imbalance in power relations between the government and the people affected by the reclamation does not make knowledge and policies with those who have absolute power. Reclamation knowledge in the community is obtained from the combined knowledge between the community and the government. The community as a party that has a power relation is weaker than the government. There is a conflict between the middle class or bluecollar society in defending the rights and beliefs that they believe in dealing with parties who have power and resources or are called white-collar groups. Public opinion about reclamation is always negative, this is because all reclamations are administratively and legally problematic but the implementation of reclamation continues to completion by ignoring the problems and crimes that have been caused.

In the case of coastal reclamation, there is a power relationship between the company or developer who is the executor of the reclamation and the government which has the authority to issue a reclamation permit. Currently, government agencies that have the authority to issue reclamation permits in the central government are the Ministry of Maritime Affairs and Fisheries, the Ministry of Environment, the Ministry of Public Works, and the Ministry of Agrarian Affairs. While in the regional government that has the authority is the City/Regency Government, and related. The time and process required in completing the reclamation administration tend to make developers take shortcuts by carrying out reclamation along with administrative arrangements, of course, because there is a good power relationship between the developer and the government. This is what makes all reclamation in Indonesia experience problems.

The implementation of reclamation carried out by developers with good power relations to the central and regional governments is unconstitutional, it can be ascertained that there will be rejected from the community. In addition, it will certainly develop into a white-collar crime. White-Collar crime committed by the Government is State Authority Occupational Crime, White Collar Crime carried out by the Company is Organizational Occupational Crime, White Collar Crime carried out by government officials or development officials is Professional Occupational Crime, and WCC carried out by non-work-related persons is Individual Occupational Crime.

There are several suggestions for coastal reclamation in Indonesia. For the government, to prioritize the Social, Economic, and Cultural aspects in the reclamation development process by placing communities affected by coastal reclamation from a humanitarian aspect that cannot be separated from development. For the government, to integrate between institutions in the coastal reclamation process to minimize violations committed by certain parties. Integration in various aspects such as licensing, implementation, to completion so that the coastal reclamation carried out has a good impact on all parties and is carried out following applicable procedures. The ideal coastal reclamation can accommodate the interests of all parties (government, developers, and the community). The government is expected to be consistent and firm with the policies that have been made. Developers hope for legal certainty and protection. The community hopes to be given access to participate in coastal reclamation and community ownership of some of the economic results of the reclamation island. 


\section{REFERENCE}

Alhamda, S., Barlian, E., Razak, A., Riyadi, B. S., Herawati, N., \& Anggara, A. T. (2020). Deviation of management of medical waste from hospital implication upon environmental damage in west sumatera, Indonesia. International Journal of Criminology and Sociology, 9, 1773-1781. https://doi.org/10.6000/1929-4409.2020.09.203

Balan, S. (2010). M. Foucault's view on power relations. Cogito: Multidisciplinary Res. J., 2, 193.

Benson, M. L., \& Simpson., S. S. (2009). White collar crime: An opportunity perspective. Routledge. https://doi.org/10.1007/978-0-387-09502-8_9

Braithwaite, J. (2010). Diagnostics of white-collar crime prevention. Criminology \& Pub. Pol'y, 9, 621. https://doi.org/10.1111/j.1745-9133.2010.00655.x

Cliff, G., \& Desilets, C. (2014). White collar crime: What it is and where it's going. Notre Dame JL Ethics \& Pub. Pol'y, (28), 481.

Creswell, J. W. (2009). Research Design: Qualitative, Quantitative, and Mixed Methods Approaches (3rd ed.). California, Thousand Oaks: Sage Publication.

Dugan, L., \& Gibbs, C. (2009). The role of organizational structure in the control of corporate crime and terrorism. In The criminology of white-collar crime. New York: Springer.

Elliott, P. (1973). Professional ideology and social situation. The Sociological Review, 21(2), 211-228. https://doi.org/10.1111/j.1467-954X.1973.tb00487.x

Emerson, R. M. (1962). Power-dependence relations. American Sociological Review, 31-41. https://doi.org/10.2307/2089716

Foucault, M., \& Kritzman, L. (2013). Politics, philosophy, culture: Interviews and other writings. Routledge. https://doi.org/10.4324/9780203760031

Green, G. S. (1990). Occupational crime. Chicago: Nelson-Hall.

Hermanto, A. B., \& Riyadi, B. S. (2020). Constitutional law on the discretionary of prosecutor's power against abuse of power implications of corruption culture in the prosecutor's office Republic of Indonesia. International Journal of Criminology and Sociology, 9(16), 763-772. https://doi.org/10.6000/1929-4409.2020.09.71

Husin, S. (2016). Reclamation in the View of the Protection of Marine Environment under the Environmental Law and the Law concerning the Management of Coastal Areas and Small Islands. Indonesian J. Int'l L., 14, 294. https://doi.org/10.17304/ijil.vol14.3.695

Michalowski, R. J., \& Kramer, R. C. (2007). State-corporate crime and criminological inquiry. In International handbook of whitecollar and corporate crime. Boston, MA.: Springer. https://doi.org/10.1007/978-0-387-34111-8 10

Miles, M. B., \& Huberman, A. M. (1994). Qualitative Data Analysis. California, Thoussand Oaks: Sage Publication.

Newman, D. J. (1958). White-collar crime. Law \& Contemp. Probs., 23, 735. https://doi.org/10.2307/1190396

Pawitro, U. (2015). Reklamasi Kawasan Pesisir Pantai: antara Pelestarian Lingkungan dan Ekonomi Kawasan. In Prosiding Temu IImiah IPLBI (pp. 30-31).
Priyandes, A., \& Majid, M. (2009). Impact of reclamation activities on the environment case study: reclamation in northern coast of Batam. Jurnal Alam Bina, 15(1).

Riyadi, B. S. (2017). Law of agrarian conflict and resolution effort: A claim dispute of Eigendom verponding Land. International Journal of Law, 3(80), 88. Retrieved from www.lawjournals.org

Riyadi, B. S. (2020a). Culture of abuse of power due to conflict of interest to corruption for too long on the management form resources of oil and gas in Indonesia. International Journal of Criminology and Sociology, 9(61), 247-254. https://doi.org/10.6000/1929-4409.2020.09.23

Riyadi, B. S. (2020b). Culture of abuse of power in indonesia from the perspective of criminology and law. International Journal of Criminology and Sociology, 9(2008), 274-284. https://doi.org/10.6000/1929-4409.2020.09.26

Riyadi, B. S., Alhamda, S., Airlambang, S., Anggreiny, R., Anggara, A. T., \& Sudaryat. (2020). Environmental damage due to hazardous and toxic pollution: A case study of citarum river, west java, Indonesia. International Journal of Criminology and Sociology, 9, 1844-1852.

https://doi.org/10.6000/1929-4409.2020.09.04

Riyadi, B. S., Atmoredjo, S., \& Sukisno, D. (2020). Underground space: The concept of property right based on theory of property rights perspective. International Journal of Law, 6(2), 26-34.

Riyadi, B. S., Hermanto, A. B., Harlina, I., \& Purnomo, H. (2020). Discretion of power of the indonesian national police impacts the abuse of power in the case of letter forgery of red notice "Fugitive Djoko Tjandra." International Journal of Criminology and Sociology, 9(October), 1292-1300. https://doi.org/10.6000/1929-4409.2020.09.148

Riyadi, B. S., Usman, \& Sudarti, E. (2020). The disparity in criminal prosecution against acid attack on investigator of corruption eradication commission: "novel baswedan" case. International Journal of Criminology and Sociology, 9, 16761687.

https://doi.org/10.6000/1929-4409.2020.09.191

Riyadi, B. S., Wibowo, B. R., \& Susanti, V. (2020). Culture of corruption politicians' behavior in parliament and state official during reform government Indonesia. International Journal of Criminology and Sociology, 9, 52-62. https://doi.org/10.6000/1929-4409.2020.09.06

Rozikin, M., Sofyan, M., Riyadi, B. S., \& Supriyono, B. (2021) Institutional capacity as prevention of abuse of power of national standard policies for private Universities in Jakarta. International Journal of Criminology and Sociology, 10, 281292.

https://doi.org/10.6000/1929-4409.2021.10.34

Sutherland, E. H. (1972). White-collar criminality. Columbia: Columbia University Press. https://doi.org/10.7312/dres92534-016

Watkins, S. D. (2010). The Impact of Brownfield Reclamation on Surrounding Land Values and Crime. Minnesota, Minneapolis: Department of Resource Analysis, Saint Mary's University.

Yin, R. K. (2009). Case Study Research: Design and Methods. Essential guide to qualitative methods in organizational research (Vol. 5). https://doi.org/10.1097/FCH.0b013e31822dda9e

\section{https://doi.org/10.6000/1929-4409.2021.10.188}

(c) 2021 Kurniawan et al.; Licensee Lifescience Global.

This is an open access article licensed under the terms of the Creative Commons Attribution License (http://creativecommons.org/licenses/by/4.0/) which permits unrestricted use, distribution and reproduction in any medium, provided the work is properly cited. 